\title{
Modeling air pollution in Beijing for the 2008 Olympic Summer Games
}

\author{
Jenni Vanos
}

This manuscript was prepared under the supervision of Profs. Jon Warland, and Terry Gillespie, Land Resource Science, Ontario Agricultural College, and Nigel Bunce, Department of Chemistry, College of Physical and Engineering Sciences.

\begin{abstract}
High levels of ambient oxidant air pollution, such as ozone, have been associated with negative health effects in elite athletes. The photochemical model OzCalc was used to calculate ozone concentrations as a function of time in Beijing for the 2008 Olympic Summer Games. By making use of the data obtained in Hastings, Ontario in August 1993, the model was adjusted for Beijing with respect to radiation geometry and ambient levels of primary air pollutants. Ozone concentrations were calculated using three scenarios: keeping pollution levels constant, a moderate success in pollution clean-up, and a high success in pollution clean-up. Results of ozone obtained with the model predicted very high levels associated with Scenario's 1 and 2, while Scenario 3 showed acceptable levels for athletic competition, in accordance with WHO and Chinese Standards. A high NO-to- $\mathrm{NO}_{2}$ concentration ratio showed less ozone formation, which displayed the dependence of ozone on the variable levels of $\mathrm{NO}_{2}$ and $\mathrm{NO}$. The level of the hydroxyl radical formation was closely related to that of ozone. The overall results suggest that Beijing will have a difficult time bringing pollution down to an acceptable level; athletes will have to deal with an added negative physiological response.
\end{abstract}

$\mathrm{T}$ he Olympic Games is a prestigious athletic event with high calibre athletes competing to the best of their ability. Athletes competing in the 1932 Los Angeles and 1948 London Olympic Games were subjected to high levels of urban air pollution. ${ }^{21}$ More than eight decades later, Beijing is hosting the 2008 Olympic summer games with a similar air quality problem. Currently, Beijing is vying for the dubious distinction of having the worst air pollution in the world. ${ }^{8}$ Therefore, as part of its bid for the Olympics, Beijing pledged to reduce its emissions, yet rapid industrialization within the city has curtailed these endeavours. China will be the first developing country to hold the Olympics. Beijing, as well of the rest of China, is heavily reliant on coal-fired power plants, and an exponential increase in automobile ownership over the last decade has rapidly amplified the air pollution problem and related health issues.

Literature studying the effects of air pollution on a sedentary person is easily obtained, whereas studies conducted on high-end athletes and their athletic performances are somewhat limited. Rarely are the sciences of human physiology and atmospheric chemistry combined to forecast the physiological responses of athletes due to high air pollution. Air pollution is the most common environmental stress affecting the training and competitive performance of an athlete. ${ }^{21}$ Due to increased rate of breathing, athletes intake more air, especially in events requiring the maximum volume of oxygen $\left(\mathrm{VO}_{2 \max }\right)$, such as running and cycling. Most of the research work has been done on the effects of elevated ozone concentrations. Ozone is a major component of urban air pollution, and warrants a public air quality advisory in Ontario when concentrations exceed $50 \mathrm{ppb}^{22}$

Many experiments have been conducted resulting in interindividual variation in response to episodic ozone exposure, such as on short-term lung damage..$^{9,16,19}$ Also, variable response in individuals of differing genotypes at low concentrations has been found, thus suggesting genetic variability. ${ }^{16}$ Adams et al. ${ }^{1}$ noted considerable individual variability to ozone toxicity when testing eight trained males at three ozone concentrations (200, 300 and $400 \mathrm{ppb})$. Study results from Adams $^{2}$ from $6.6 \mathrm{~h}$ exposure to $80 \mathrm{ppb} \mathrm{O}_{3}$ revealed several incongruities that may be due primarily to high individual subject variability in pulmonary responses to a relatively low $\mathrm{O}_{3}$ exposure. Yet, at concentrations of 120 $\mathrm{ppb}$, he found insignificant differences among the same 30 
healthy test subjects. These finding suggest that there is increased variability with lower concentrations, and similar responses with higher concentrations.

Most athletes will not know how their body will respond to the levels of air pollution in Beijing due to this subjective variability. ${ }^{16,19}$ There is some evidence that adaptation can occur in those that are exposed to ozone, allowing them to respond less negatively upon re-exposure due to conditioning of the respiratory system. ${ }^{14}$ This is dependent on factors subjective to each individual, such as sensitivity to the type

of pollutant, previous exposure, nutrition, age and genetics. Folinsbee et al. ${ }^{16}$ tested male subjects at ozone concentrations of $120 \mathrm{ppb}$. After five days of $6.6 \mathrm{~h}$ exposure, they found responses decreased each day. For days 1 and 2, the range between the subjects was 0 to $34 \%$ for forced expiratory volume in one second (FEV1). They also found symptoms of cough and chest pains were greatest for all individuals on day one, thus suggesting adaptation.

Foxcroft and Adams ${ }^{17}$ found that becoming conditioned to high ambient concentrations could help the athlete in competition in the short term (1-2 days), but inducing longterm exposure should be avoided. Similar observations from Schonfeld et al. ${ }^{25}$ demonstrated that enhanced pulmonary function persists up to $24 \mathrm{~h}$, and possibly up to $48 \mathrm{~h}$ for some individuals, but is absent $72 \mathrm{~h}$ after initial exposure. Further studies are needed to identify the benefits of improved shortterm pulmonary responses to ozone versus the health implications of inducing subjects to high concentrations. Asthmatic athletes will have even greater trouble dealing with the air pollution. Approximately $5-20 \%$ of the athletes competing at the Athens Olympics in 2004 had asthma ${ }^{15}$.

The objective of this study is to use to use the numerical model OzCalc to predict the ambient oxidant air pollution levels at the 2008 Olympic Summer Games in Beijing, based on Beijing's current pollution and some possible improvements in air quality. This study focused mainly on the primary pollutants of $\mathrm{NO}_{\mathrm{x}}$, the secondary pollutant $\mathrm{O}_{3}$, and the $\mathrm{OH}$ radical, which are all related to vehicle combustion and health problems. In order to predict ambient pollution levels, three different scenarios were projected. These include: keeping pollution levels constant, moderate success in pollution clean-up and a high success in pollution clean-up. Based on these results, conditions for competitors at the 2008 Olympics will be predicted and recommendations will be made on steps that Beijing must take to reduce the air quality problem to an acceptable level.

\section{AtMosphere IN BEIJING}

With a population of 14 million, ${ }^{6}$ Beijing is vying with Mexico City as the most polluted city in the world. ${ }^{8}$ Extensive research has been completed to address pollutants associated with Beijing's coal combustion and automobile
Table 1: China's Daily Air Quality Standards in ppb. Beijing uses Grade II as its urban standard during the summer ${ }^{8}$.

\begin{tabular}{|c|c|c|c|c|}
\hline & $\begin{array}{c}\mathbf{P M}_{10} \\
(\mathbf{p p b})\end{array}$ & $\begin{array}{c}\mathbf{O}_{3} \\
(\mathbf{p p b})\end{array}$ & $\begin{array}{c}\mathbf{S O}_{\mathbf{2}} \\
(\mathbf{p p b})\end{array}$ & $\begin{array}{c}\text { TSP } \\
(\mathbf{p p b}\end{array}$ \\
\hline Grade I & 50 & 80 & 50 & 120 \\
\hline Grade II & 150 & 100 & 150 & 300 \\
\hline $\begin{array}{c}\text { Grade } \\
\text { III }\end{array}$ & 250 & 100 & 250 & 500 \\
\hline
\end{tabular}

Table 2: Average annual concentrations and WHO Guidelines of common pollutants found in Beijing in $\mu \mathrm{g} \mathrm{m}$. WHO measurements differ in length of time with respect to each pollutant due to differing responses of human health.

\begin{tabular}{|c|c|c|c|}
\hline Pollutant & $\begin{array}{l}\text { Beijing } \\
\text { Annual } \\
\text { Average } \\
\text { (ppb) }\end{array}$ & Source & $\begin{array}{c}\text { WHO } \\
\text { Guidelines } \\
(2000)\end{array}$ \\
\hline $\mathbf{P M}_{10}$ & 94-250 & $\begin{array}{l}\text { Bergin et al., } \\
\text { (2001); Chan } \\
\text { et al. (2005) }\end{array}$ & $\begin{array}{l}20(24 \mathrm{~h} \\
\text { mean })\end{array}$ \\
\hline $\mathbf{P M}_{2.5}$ & 91-169 & $\begin{array}{l}\text { Bergin et al., } \\
\text { (2001); Chan } \\
\text { et al. (2005) }\end{array}$ & $\begin{array}{l}10(24 \mathrm{~h} \\
\text { mean })\end{array}$ \\
\hline $\mathbf{O}_{3}$ & 235 & $\begin{array}{l}\text { Streets et al. } \\
\quad(2007)\end{array}$ & $\begin{array}{l}100(8 \mathrm{~h} \\
\text { mean })\end{array}$ \\
\hline $\mathrm{NO}_{2}$ & 71 & $\begin{array}{c}\text { Beijing EPB } \\
(2000)\end{array}$ & $\begin{array}{c}40 \\
\text { (annual) }\end{array}$ \\
\hline TSP & 353 & $\begin{array}{c}\text { Beijing EPB } \\
\text { (2000) }\end{array}$ & $\begin{array}{c}90 \\
\text { (annual) }\end{array}$ \\
\hline $\mathrm{SO}_{2}$ & 71 & $\begin{array}{c}\text { Beijing EPB } \\
(2000)\end{array}$ & $\begin{array}{c}40 \\
\text { (annual) }\end{array}$ \\
\hline
\end{tabular}

pollution. This has lead to increased efforts to understand the unique reactions occurring within the city, as well as the importance of geography and temporal variations. Beijing is located on the north-western border of the Great North China Plain, surrounded by mountains, except in the south ${ }^{20}$. Mountains act as barriers, trapping air pollution in the city, especially with increased atmospheric stability. Pollutants also travel in from the south easily, due to southerly winds and few mountains, but have a much harder time escaping the city. Thus, pollutant concentrations in Beijing are highly dependent on its geography, the surrounding municipalities' pollution, and weather patterns.

China's daily air quality standards are shown in Table $\mathbf{1 .}$ The standard used for urban areas like Beijing is Grade II. ${ }^{26}$ Actual ambient levels of these pollutants, and others, are displayed in Table 2 for comparison. In Beijing, the annual average levels in 2000 for total suspended particles (TSP), $\mathrm{SO}_{2}$, and $\mathrm{NO}_{2}$ stood at $392 \%, 178 \%$ and $142 \%$ respectively, with respect to World Health Organization (WHO) standards $^{8}$. TSP, largely made up of particulate matter less 
than $2.5 \mu \mathrm{m}$ in diameter $\left(\mathrm{PM}_{2.5}\right)$, along with ozone, has been found to have increasingly negative effects on the systemic vasculature of humans ${ }^{9}$ as well as producing irritation symptoms. $^{21}$

Vehicle emissions and coal combustion form the primary reactants of $\mathrm{CO}, \mathrm{SO}_{\mathrm{x}}, \mathrm{NO}_{\mathrm{x}}$ and $\mathrm{PM}$, giving rise to secondary oxidant pollution: $\mathrm{O}_{3}{ }^{21} \mathrm{NO}$ is converted in ambient air to form $\mathrm{NO}_{2}$, therefore $\mathrm{NO}$ is both a primary and secondary reactant. ${ }^{13}$ An increase in emissions from vehicles in Beijing is changing atmospheric chemistry from typical coalcombustion pollution to compound pollution, with $\mathrm{O}_{3}$ and fine particles causing the most problems. ${ }^{29}$ Zhang et al. ${ }^{29}$ proposed that the effective way to reduce photochemical smog is to decrease $\mathrm{NO}_{\mathrm{x}}$ emissions, the prime component in vehicle combustion. Fossil fuel and coal combustion result in high amounts of volatile organic compounds (VOC's), which are tiny particles which vaporize into the atmosphere and take part in photochemical reactions.

Nitrogen oxides include $\mathrm{NO}$ and $\mathrm{NO}_{2}$ and are at the center of atmospheric photochemistry as they are fundamental in many chemical reactions. The following reaction scheme is the natural ozone formation process in which it is created and destroyed. In a clean atmosphere, it would give a desirable ozone concentration of 20-30 ppb. ${ }^{18}$

$$
\begin{aligned}
& \mathrm{NO}_{2}+h v \rightarrow \mathrm{NO}+\mathrm{O} \\
& \mathrm{O}+\mathrm{O}_{2} \rightarrow \mathrm{O}_{3} \\
& \mathrm{O}_{3}+\mathrm{NO} \rightarrow \mathrm{NO}_{2}+\mathrm{O}_{2}
\end{aligned}
$$

A controlling effect of $\mathrm{O}_{3}$ is shown by Eqn. (3) in which it is naturally broken down.

Within the troposphere, VOC's are photolyzed and react with $\mathrm{OH}$ and $\mathrm{NO}_{3}$ radicals to form organic peroxy radicals $\left(\mathrm{RO}_{2} \bullet\right)$, leading to formation of $\mathrm{NO}_{2}$ from $\mathrm{NO}$, the $\mathrm{OH}$ radical, and $\mathrm{O}_{3}$. Radicals are more reactive because they have unpaired electrons. A mechanistic scheme for VOC formation and reaction is shown in (4) and (5).

$$
\begin{aligned}
& \text { VOC }\left(+h v, \mathrm{OH}, \mathrm{NO}_{3}, \mathrm{O}_{3}\right) \rightarrow \alpha \mathrm{RO}_{2} \bullet \\
& \mathrm{RO}_{2} \bullet+\beta \mathrm{NO} \rightarrow \gamma \mathrm{NO}_{2}+\delta \mathrm{OH}
\end{aligned}
$$

One of the simplest examples of a VOC driven reaction is shown in Eqn. (6).

$$
\mathrm{HO}_{2}+\mathrm{NO} \rightarrow \mathrm{OH}+\mathrm{NO}_{2}
$$

When $\mathrm{NO}_{2}$ is generated in this way, as shown in Eqns. (5) and (6), then the photolytic cycle can proceed without reaction (3) occurring.

One of the most important radicals is the $\mathrm{OH}$ radical, which reacts very quickly with other species. Barrett et al. ${ }^{4}$ predicted the concentration of $\mathrm{OH}$ to be directly related to the rate of photolysis of ozone, since $\mathrm{OH}$ is a common product of ozone reactions.

$$
\mathrm{HO}_{2}+\mathrm{O}_{3} \rightarrow \mathrm{OH}+2 \mathrm{O}_{2}
$$

In terms of $\mathrm{OH}$ sinks, $\mathrm{NO}_{2}$ seems to be the strongest in urban conditions since it can effectively titrate $\mathrm{OH}$ out of the atmosphere ${ }^{4}$.

$$
\mathrm{OH}+\mathrm{NO}_{2} \rightarrow \mathrm{HNO}_{3}
$$

The level of VOC's within the troposphere is an important constituent in reactions. VOC's are either anthropogenic or biogenic (vegetation), and mix with $\mathrm{NO}_{\mathrm{x}}$ to form pollution. ${ }^{10}$ The annual VOC emission level in 1998 for Beijing was 1.6 $\mathrm{x} 10^{10} \mathrm{~g}-\mathrm{C}^{29}$. Forty-eight percent of this came from isoprene, the most common biogenic $\mathrm{VOC},{ }^{29}$ which plays an important role in photochemical processes since it cannot easily be removed from the air.

Daily air pollution variation studies in Beijing during the summer time show increased levels of $\mathrm{O}_{3}$ during times with the highest temperatures and humidity, due to photochemical formation. ${ }^{27}$ When $\mathrm{NO}_{2}$ photochemically dissociates under troposphere radiation conditions, it results in $\mathrm{NO}$ and $\mathrm{O}$ formation, shown in the following reactions:

$$
\begin{aligned}
& \mathrm{NO}_{2}+h v \rightarrow \mathrm{NO}+\mathrm{O} \\
& \mathrm{NO}_{2}+\mathrm{O}_{2}+h v \rightarrow \mathrm{O}_{3}+\mathrm{NO}
\end{aligned}
$$

Ozone is also formed by reaction with oxidizable substrates. The overall reaction in this case is:

$$
\mathrm{CO}+2 \mathrm{O}_{2}+h v \rightarrow \mathrm{CO}_{2}+\mathrm{O}_{3}
$$

These products can then be used in subsequent reactions to form $\mathrm{NO}_{2}$ and $\mathrm{O}_{3}$, respectively. The reaction of $\mathrm{NO}$ with $\mathrm{O}_{3}$ controls the development of the $\mathrm{O}_{3}$ peak in urban areas; ${ }^{13}$ therefore the time of peak traffic has shown close association with peak $\mathrm{O}_{3}$ values.

The rate of Eqn. (3) can be reduced during times of decreased [NO], hence increasing $\left[\mathrm{O}_{3}\right]$, and decreasing $\left[\mathrm{NO}_{2}\right]$. It is also shown by the reaction in Eqn. (3) that an increase in [NO] will deplete the atmosphere of $\mathrm{O}_{3}$, yet increase concentrations of $\mathrm{NO}_{2}$. Sometimes when $\mathrm{NO}_{\mathrm{x}}$ emissions are removed from the convective boundary layer, an increase in $\mathrm{O}_{3}$ occurs due to the nonlinear relation of model response to emission changes. ${ }^{26}$ Streets et al. ${ }^{26}$ explain that this phenomenon is called the " $\mathrm{NO}_{\mathrm{x}}$ disbenefit", associated with reaction (3) becoming inhibited, and reaction (10) progressing forward. Atmospheric nitrogen in the form of $\mathrm{N}_{2}$ can also be converted into $\mathrm{NO}$ by binding with $\mathrm{O}_{2}$ in the presence of heat because it is an endothermic reaction. ${ }^{10}$ $\mathrm{Xu}$ et al. ${ }^{28}$ employed a model to simulate $\mathrm{O}_{3}$ formation in the summer in Beijing and studied four heterogeneous reactions associated with its formation. The four reactions include: 


$$
\begin{aligned}
& \mathrm{HO}_{2} \rightarrow 1 / 2 \mathrm{H}_{2} \mathrm{O}_{2} \\
& \mathrm{NO}_{2} \rightarrow 1 / 2 \mathrm{HONO}+1 / 2 \mathrm{HNO}_{3} \\
& \mathrm{NO}_{3} \rightarrow \mathrm{HNO}_{3} \\
& \mathrm{~N}_{2} \mathrm{O}_{5} \rightarrow 2 \mathrm{HNO}_{3}
\end{aligned}
$$

All four of the reactions require PM as an agent for the reaction to proceed. Results from Xu et al. ${ }^{28}$ showed a VOC limited regime within the city because these aerosols (VOC's) provide a large surface area on which these four reactions occur. They also found that the $\mathrm{NO}_{2}$ and $\mathrm{HO}_{2}$ reactions had the most severe impact on ozone formation, with $\mathrm{NO}_{2}$ increasing $\mathrm{O}_{3}$ concentration and $\mathrm{HO}_{2}$ decreasing it. This is because throughout $\mathrm{O}_{3}$ formation, the $\mathrm{NO}_{2}$ heterogeneous reaction (Eqn. 13) increased new radical creation by $30 \%$, raising the atmospheric activity as more NO-to- $\mathrm{NO}_{2}$ conversion occurred, thus causing $\mathrm{O}_{3}$ to rise. ${ }^{28}$ Therefore, the $\mathrm{HO}_{2}$ reaction (Eqn. 12) can eliminate radicals directly. All of the maximum impacts from the $\mathrm{NO}_{2}$ reaction occurred at the Olympic Center, which is downwind of the urban center. Xu et al. ${ }^{28}$ observed a net increase in $\mathrm{O}_{3}$ at this location (due to all four heterogeneous reactions) to be 15 $\mathrm{ppb}$, followed the next day by a $50 \mathrm{ppb}$ increase at Peking University due to wind direction changes.

Polycyclic aromatic hydrocarbons (PAH's) and suspended particulate matter (SPM) are anthropogenic VOC's which provide a surface for reactions to occur on. ${ }^{3}$ In a study on PAH's in a residential area of Beijing, Ando et al. ${ }^{3}$ found higher concentrations in PAH's with an aerodynamic diameter $<0.2 \mu \mathrm{m}$ (fine particulate matter). Incomplete combustion spews many sizes of PM into the atmosphere, but fine PM is more persistent due to its low weight. Also, due to their small size, particles $\leq \mathrm{PM}_{2.5}$ can easily enter and be absorbed by the respiratory tract in addition to carrying toxic gases which normally would not be absorbed (due to high solubility). ${ }^{21}$ Ando et al. ${ }^{3}$ found a significant correlation between mutagenic activities in humans and $\mathrm{PAH}$ concentration in the PM, thus showing the inherent concern to human health due to added vehicle and coal combustion.

\section{MODEL}

A computer model based on photochemical reactions that form ozone was developed in 1993 by Barrett, Bunce and Gillespie, ${ }^{4}$ at the University of Guelph. Entitled 'Ozcalc', this model estimates the calculated concentration of ozone as a function of time, treating ozone concentration as the only dependent variable. It has the ability to estimate the concentration in a near-stationary mass in the troposphere as well as predict chemical maturation of an air mass using calculations of appearance and disappearance of product species. ${ }^{4}$ It focuses on the major chemical processes associated with the formation of photochemical smog, while avoiding the intermediate steps that are more difficult to model. Therefore, calculations involve concentrations of all reactant species and the associated rate constants. Drawbacks of this model include estimating concentrations of some radicals and not considering advection, although their findings were validated with field data.

In development of this model, data from SONTOS (Southern Ontario Oxidants Study) was used, in which hundreds of scientists gathered to simultaneously collect atmospheric data. ${ }^{7}$ Atmospheric scientists in Beijing have never gathered to produce an experimental oxidant study like SONTOS. Hence, this study is limited to using a 'pseudodata set' from Hastings, Ontario (downwind from major urban pollution sources) to determine what occurs when the concentrations from Hastings are changed in accordance with knowledge of the components of Beijing's atmosphere. The photochemical rate constant, cloud cover and zenith angle are taken into consideration for calculations within the OzCalc model. This is because the cleavage of many species is dependant on the intensity of solar radiation.

When the static offsets are initially set to zero, the resultant graphs will show the measured data throughout the day. Entering any value other than zero into the static offsets results in the value of that variable being higher or lower throughout the whole day. By changing the static offsets of $\mathrm{CO}(\mathrm{ppb}), \mathrm{NO}_{2}(\mathrm{ppb})$, isoprene (ppb), $\mathrm{NO}(\mathrm{ppb})$, relative humidity $(\%)$ and temperature $\left({ }^{\circ} \mathrm{C}\right)$, specific manipulations suited to Beijing can be made.

Experimental findings by Barrett et al. $^{4}$ indicated that changes in the concentration of $\mathrm{NO}_{\mathrm{x}}$ and light intensity were a much greater force upon ozone formation than relative humidity and hydrocarbon concentrations. They also found that thermal decomposition of peroxyacetyl nitrate (PAN) was the main driver behind ozone concentration dependence on temperature.

By making use of the OzCalc model, calculated pollution will be predicted for conditions pertaining to the city of Beijing. By the beginning of the $21^{\text {st }}$ century, China had implemented many measures for decreasing its emissions, ${ }^{26}$ yet growth has imposed constraints on attempts to reduce the negative influences of ozone, $\mathrm{PM}_{2.5}$ and other air pollutants on athletic performances. Due to the increase in anthropogenic emissions in Beijing and surrounding provinces, as well as the complex meteorological characteristics of the city, estimation of ambient pollutant concentrations during the 2008 Summer Olympic Games requires a multifaceted approach.

\section{RESEARCH APPROACH}

Three projected pollution levels were developed for Beijing and used as scenarios for this study. Scenario 1 projects that current pollution levels remain, Scenario 2 assumes a moderate level of pollution clean-up, and Scenario 3 assesses the pollution with a traffic ban put in place. 
Since isoprene is a biogenic VOC, the concentration does not change unless significant changes to vegetation in Beijing occur. For all experiments (unless otherwise stated), a static offset of $0.77 \mathrm{ppb}$ of isoprene was used (average level in Beijing above that of Hastings). Carbon monoxide, temperature and relative humidity were not altered from the Hastings values, as they do not differ significantly from summer conditions in Beijing. Barrett et al. ${ }^{4}$ found that $\mathrm{O}_{3}$ was relatively unresponsive to their changes. $\mathrm{NO}$ and $\mathrm{NO}_{2}$ were altered with respect to each scenario tested.

For all three scenarios, the radiation geometry - which included the solar declination and right ascension - for the date of August 21 were used. On this date, there are multiple semi-final and final sections planned for Track and Field in the morning and evening, as well as the women's final Soccer match in the early evening ${ }^{5}$. This day is well representative of surrounding days. The Hastings' data file used was August 25, 1993 which was ideally suited for the non-advective approach ${ }^{4}$, which OzCalc uses. On this day, the winds were variable from all directions with low speeds consistently $<12 \mathrm{~km} \mathrm{hr}^{-1}$, which is common in Beijing since it is surrounded by hills on three sides.

Since Beijing's current air pollution data is not readily available, in particular for $\mathrm{NO}$ and $\mathrm{NO}_{2},{ }^{7}$ air pollution data from downtown Windsor, Ontario on a poor air quality day were used to represent a normal day in Beijing. July 16, 2006 was chosen because it had an Air Quality Index of 52, or very poor ${ }^{22}$. The resulting $[\mathrm{NO}] /\left[\mathrm{NO}_{2}\right]$ ratio was approximately 0.098 , with $\mathrm{NO}_{2}=23.2 \mathrm{ppb}$ and $\mathrm{NO}=2.3 \mathrm{ppb}$. $\mathrm{NO}_{2}$ and $\mathrm{NO}$ levels were approximately 22.5 and $2.2 \mathrm{ppb}$ respectively, above the associated values from Hastings. Therefore, these concentration increases were used as the static offsets for the first scenario.

In Scenario 2, the reduction of pollution used was in accordance with a study completed by Brajer and $\mathrm{Mead}^{8}$ that projected health improvements from what they called "The Olympic Effect". They made use of pollution data from 1998, 1999, and 2000 from the Chinese Environmental Protection Bureau, accounting for spatial and temporal variability. The current study made partial use of this scenario of emission control efforts that projected an annual decrease of $3 \%$ from 2000 to 2005, which suggests a moderate degree of success from emission control efforts. They note that this $15 \%$ reduction is higher than several other projections of $10 \%$ total. Therefore, this current study projected a decrease in $\mathrm{NO}$ and $\mathrm{NO}_{2}$ of $19 \%$ (10\% for 2000 to 2005 , and $9 \%$ for 2006 to 2008) from the benchmark levels in Scenario 1. For purposes of this current study, Scenario 1 concentrations were assumed to be 'benchmark' pollution levels from the year 2000. This is when Beijing began significant clean up efforts ${ }^{8}$. This resulted in $\mathrm{NO}_{2}$ and NO concentrations of 18.3 and $1.8 \mathrm{ppb}$, which are $17.7 \mathrm{ppb}$ and $1.7 \mathrm{ppb}$ above that of the Hastings, data respectively.

The third scenario was based on a news release by the NASA Earth Observatory ${ }^{23}$ on a traffic pollution ban in
Beijing from November $4^{\text {th }}$ to $6^{\text {th }}$ in 2006. On these days, traffic in Beijing was restricted in order to observe reduction of primary and secondary air pollutants within the city. Since one of Beijing's most common air pollutants is $\mathrm{NO}_{2}$ from vehicle emissions, the NASA Earth Observatory ${ }^{23}$ modelled $\mathrm{NO}_{2}$ concentrations over the whole month. Scientists who ran the study concluded that estimated $\mathrm{NO}_{2}$ emissions were reduced by $40 \%$. Thus, the third Ozcalc experiment for Beijing reduced the benchmark $\mathrm{NO}_{2}$ concentration from $22.5 \mathrm{ppb}$ to $13.5 \mathrm{ppb}$, while leaving NO at $2.2 \mathrm{ppb}$.

\section{RESULTS AND DISCUSSION}

Figure 1 shows the results of $\left[\mathrm{O}_{3}\right]$ and $[\mathrm{OH}]$ for Scenario 1 . Ozone concentrations are extremely high, almost reaching $180 \mathrm{ppbv}$ at 1:00 pm, which is approximately $350 \mathrm{ppb}$ or $0.35 \mathrm{ppm}$. This occurred when the concentrations of $\mathrm{NO}_{2}$ were very high, with an $[\mathrm{NO}] /\left[\mathrm{NO}_{2}\right]$ ratio of 0.098 . An initial explanation for this is that the OzCalc model is very sensitive to small changes in $\mathrm{NO}$ and $\mathrm{NO}_{2}$, but as demonstrated in Eqns. (11), (3), (9) and (10), $\mathrm{NO}_{2}$ is a source of $\mathrm{O}_{3}$ in the lower atmosphere. The $2.2 \mathrm{ppb}$ of $\mathrm{NO}$ in this experiment would have partially been used in consuming $\mathrm{O}_{3}$ (Eqn. 3), but also in forming $\mathrm{OH}$ (Eqns. 5 and 6), and $\mathrm{NO}_{2}$ (Eqns. 3, 5 and 6), which are both precursors to ozone formation.

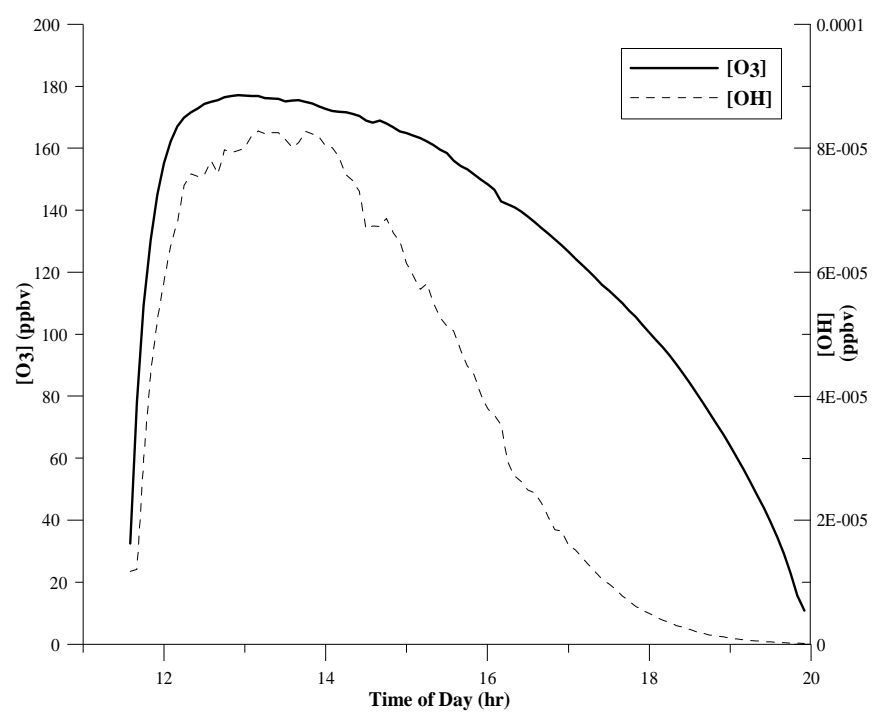

Figure 1: Graph of $\left[\mathrm{O}_{3}\right]$ and $[\mathrm{OH}]$ as functions of time-of-day for Scenario 1 (no change in pollution) by OzCalc for August 21,2008 . Concentrations reported in ppbv, converted to ppb in.

By increasing the value of the $[\mathrm{NO}] /\left[\mathrm{NO}_{2}\right]$ ratio from 0.098 to 0.2 - which is only a $2.3 \mathrm{ppb}$ increase in NO - the levels of ozone significantly decreased. This is shown as scenario $1 \mathrm{~b}$ in Table 3. 
The $\mathrm{OH}$ concentrations in Figure 1 follow closely to that of $\mathrm{O}_{3}$. This is because $\mathrm{OH}$ is associated with enhanced ozone formation, when $\mathrm{O}_{3}$ reacts with $\mathrm{HO}_{2}$ to form $\mathrm{OH}$ (Eqn. 7). $\mathrm{OH}$ is also formed due to the reaction of water with excited oxygen atoms $\left(\mathrm{O}^{*}\right)$, which are formed due to the photolysis of $\mathrm{O}_{3}$.

Results from Scenario 2 are shown in Figure 2 where a peak of $178 \mathrm{ppbv}$ is reached at 1:18 PM, which is equal to approximately $349 \mathrm{ppb}$. In Scenario 2, the reduction of NO and $\mathrm{NO}_{2}$ by $19 \%$ resulted in a peak concentration of $\mathrm{O}_{3}$ very similar to that of Scenario 1, peaking a few minutes later in the day. Throughout the day, ozone concentrations were consistently higher for Scenario 2. At 6:00 pm, the ozone concentration was $6 \mathrm{ppb}$ above Scenario 1, at $202 \mathrm{ppb}$. This can be explained because $[\mathrm{NO}] /\left[\mathrm{NO}_{2}\right]$ decreased by 0.002 for Scenario 2. This small change caused more ozone formation to occur since there was more $\mathrm{NO}_{2}$ and less $\mathrm{NO}$ in the air than in Scenario 1, which implies that the ratio of NO-to$\mathrm{NO}_{2}$ is more important than the absolute values at high concentrations of these gases. This increase in $\mathrm{O}_{3}$ caused a large influx of $\mathrm{OH}$ into the air as well.

When isoprene was removed for Scenario 2, there was no change in ozone concentration. This can be explained because isoprene reacts quickly with $\mathrm{OH}$ in the troposphere $(1.8 \mathrm{~h}){ }^{24}$ Large quantities of $\mathrm{OH}$ are formed due to the formation of $\mathrm{O}_{3}$ from $\mathrm{NO}_{2}$, as well as other atmospheric constituents such as CO (Eqn. 11). Since isoprene reacts quickly with $\mathrm{OH}$, then an abundance of $\mathrm{OH}$ can effectively remove isoprene in both high and low concentration scenarios creating $\mathrm{NO}_{2}$, which forms $\mathrm{O}_{3}$ (Eqns. 1 and 2). Thus, a seemingly large concentration change in isoprene had little to no effect on the ozone concentrations throughout the day. Another possible explanation for this is that the relative levels of isoprene are low with respect to $\mathrm{NO}_{2}(0.77$ ppb increase versus $18.3 \mathrm{ppb}$ ) and other VOC's are very low, so the resultant $\mathrm{NO}_{2}$ formed (Eqns. 4 and 5) is comparatively low.

By comparing the differences between Scenario 1 and 2, the overall observation is that it will take more than a $19 \%$ reduction to improve air quality to accepted levels. The predicted values reaching $350 \mathrm{ppb}$ mid-day and hovering around $200 \mathrm{ppb}$ in the early evening are much higher than the $100 \mathrm{ppb} 8$-hour mean standard set by China. The $8 \mathrm{~h}$ means for Scenario 1 and 2 were 255 and $258 \mathrm{ppb}$, respectively.

For Scenario 3, $\mathrm{NO}_{2}$ was reduced by $40 \%$, while leaving $\mathrm{NO}$ at the Scenario 1 level of $2.2 \mathrm{ppb}$. These inputs are based on the study completed by the NASA Earth Observatory in 2006 that found a $40 \%$ decrease in $\mathrm{NO}_{2}$. The resultant graph is shown in Figure 3. The ratio of $\mathrm{NO}-$ to- $\mathrm{NO}_{2}$ was 0.16 . The resulting concentration of $\mathrm{O}_{3}$ around 1:00 pm was 160 ppbv, which is 206ppb, and 144ppb below that of Scenario 1.

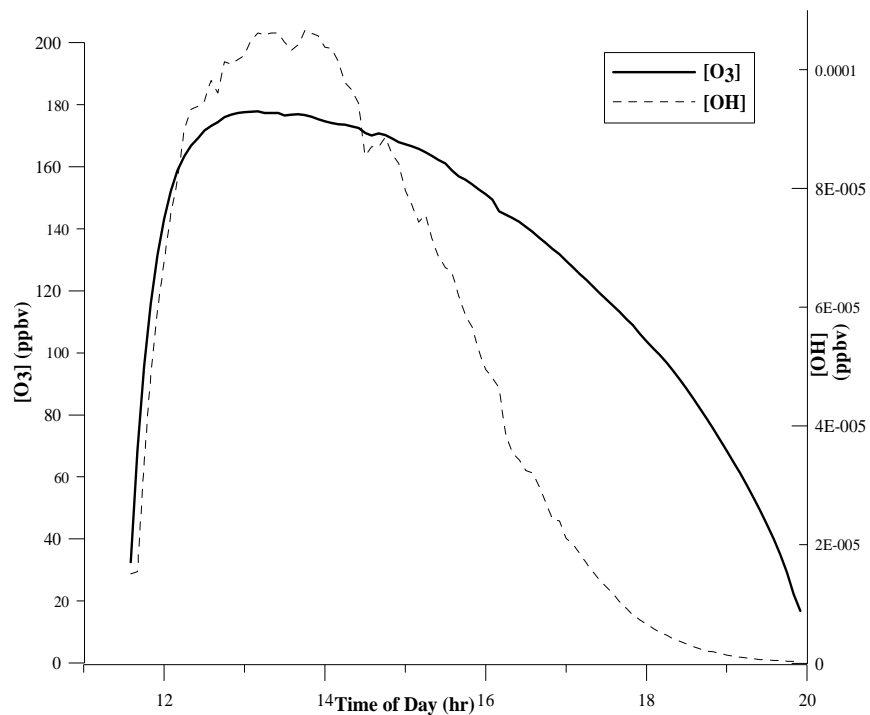

Figure 2: Graph of $\left[\mathrm{O}_{3}\right]$ and $[\mathrm{OH}]$ for Scenario 2 (19\% reduction in $\mathrm{NO}_{2}$ and $\mathrm{NO}$ ) by OzCalc for August 21, 2008. Concentrations reported in ppbv, converted to ppb in text.

This level remained relatively constant until 3:00 pm, when it began to steadily decline. At 6:00 pm, the $\mathrm{O}_{3}$ concentration was reduced to approximately $115 \mathrm{ppb}$. The 8 hour average from 11:00 am to 8:00 pm was $153 \mathrm{ppb}$. These results are still greater than the standards proposed by China and WHO, although large reductions from Scenario 1 and 2 did occur. This can be explained due to large decreases in $\mathrm{NO}_{2}$, as well as a higher $[\mathrm{NO}] /\left[\mathrm{NO}_{2}\right]$ ratio.

The large concentration differences between $\mathrm{OH}$ and $\mathrm{O}_{3}$ in Scenario 3 are due to more sources of $\mathrm{OH}$ being present than sinks. Since $\mathrm{OH}$ can be formed by $\mathrm{NO}, \mathrm{NO}_{2}$ and $\mathrm{CO}$, the increased ratio of NO-to- $\mathrm{NO}_{2}$ caused there to be more $\mathrm{NO}$ present to form $\mathrm{OH}$, thus increasing the sources. Sources of $\mathrm{OH}$ are $\mathrm{HO}_{2}$ (Eqs. 6 and 7), ozone (Eq. 7) and $\mathrm{NO}$ (Eq. 5). $\mathrm{OH}$ can also be formed be reaction of water or an excited oxygen molecule, O*. Sinks of $\mathrm{OH}$ include $\mathrm{CO}$ (Eq. 11), VOC's (Eq. 4), and $\mathrm{NO}_{2}$ (Eq. 8). Although there are both sinks and sources present, many of the sinks result in the development of species that are precursors to $\mathrm{OH}$ formation, thus, a high concentration of $\mathrm{O}_{3}$ is not the only predictor of $[\mathrm{OH}]$. Also, each gaseous species has a unique lifetime in the atmosphere, and each reaction has a separate rate of reaction. For example, the VOC methane has a lifetime due to reaction with $\mathrm{OH}$ of approximately 12 years, while the VOC's isoprene, propene and $\alpha$-pinene have lifetimes due to reaction with $\mathrm{OH}$ of $1.8 \mathrm{~h}, 7.0 \mathrm{~h}$ and $3.4 \mathrm{hrs}$, respectively. ${ }^{24}$ Thus, the reactions shown in Eqn. 4 take longer or shorter times depending on the compounds involved. 


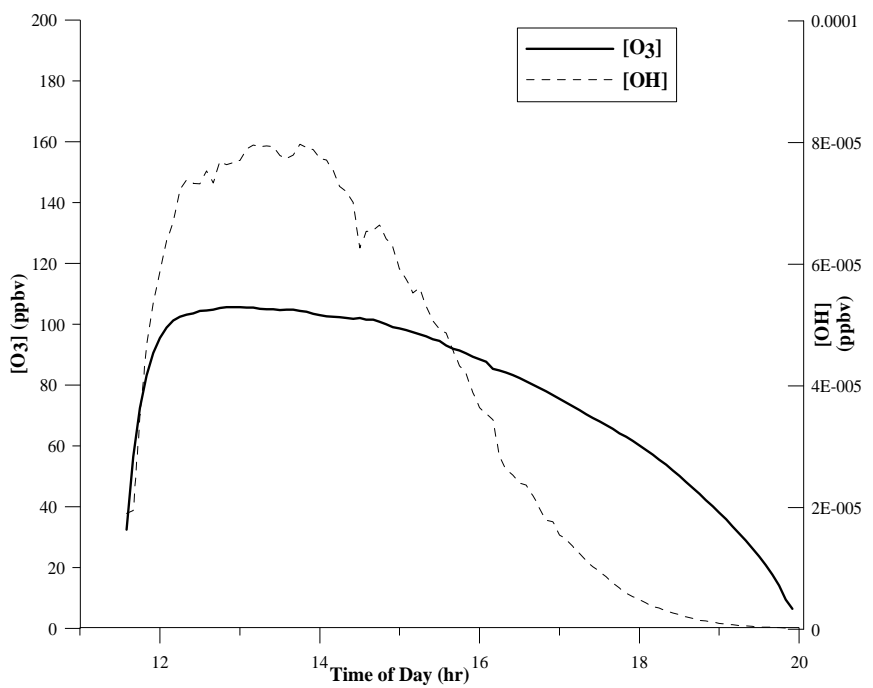

Figure 3. Graph of $\left[\mathrm{O}_{3}\right]$ and $[\mathrm{OH}]$ for Scenario $3(40 \%$ reduction in $\mathrm{NO}_{2}$ ) by OzCalc for August $21^{\text {st }} 2008$. Concentrations reported in ppbv, converted to ppb in text.

Overall results of all three scenarios are displayed in Table 3. In all three of the scenarios, $\mathrm{O}_{3}$ decreased only slowly from near-noon peak concentrations as the afternoon progressed. When the zenith angle of the sun is $0^{\circ}$, the maximum intensity of sunlight is present, thus it coincides with peak ozone concentrations due to the photochemical reactions. Since many athletic competitions will be held during the afternoon hours for spectator purposes, ${ }^{5}$ this high air pollution will coincide with maximal athletic activity. As the sun's angle increases, the amount of photons the troposphere receives decreases and the photochemistry declines. Once the sun sets at night time, all of the photochemical processes within the troposphere stop. At this time, NO in Eqn. 3 can continue to destroy ozone because there are still sources of NO from traffic within the city. For this reason, some metropolitan areas will have lower ozone concentrations than the surrounding rural areas that are not subjected to such high levels of NO. However, Beijing also receives pollutants and ozone from neighbouring cities, depending on the wind direction. During constant wind flow from the south, the neighbouring province of Heibi can contribute $50-70 \%$ of Beijing's $\mathrm{PM}_{2.5}$ and $20-30 \%$ of ozone. ${ }^{26}$ OzCalc calculations do not take this transport into consideration.

The results show that $\left[\mathrm{O}_{3}\right]$ is very sensitive to changes in the $[\mathrm{NO}] /\left[\mathrm{NO}_{2}\right]$. By separately changing these concentrations to create different ratios, the relative change in $\mathrm{O}_{3}$ was observed. Improved results might be obtained if data was available on separate concentrations of $\mathrm{NO}$ and $\mathrm{NO}_{2}$ in Beijing. By finding the optimal ratio of $\mathrm{NO}$ to $\mathrm{NO}_{2}$, the proper recommendations for comparative reductions can be made.

A drawback of many monitoring stations is that they only report $\mathrm{NO}_{\mathrm{x}}$, instead of $\mathrm{NO}$ and $\mathrm{NO}_{2}$ separately. The data from Windsor contained separate values, which made it possible to input the specific numbers into the model. Since $\mathrm{NO}$ and $\mathrm{NO}_{2}$ have such different functions in $\mathrm{O}_{3}, \mathrm{PAN}$ and $\mathrm{OH}$ formation, monitoring stations should implement separate measurements.

\section{CONClusions}

Athletes travelling to Beijing for the 2008 Olympic Games will undoubtedly be subjected to an added physiological response from high levels of air pollution. Athletes are affected by high air pollution levels more than the sedentary individual due to increased respiration and transition from nose to mouth breathing. Many studies in the past five decades have shown this, yet urban air pollution levels in Beijing remain high. The current study attempted to investigate the specific atmospheric conditions expected in Beijing in August 2008, in relation to health and performance of elite athletes.

Based on the current OzCalc model results and background research on air pollution in Beijing, it was found that ozone and PM concentrations are at very high levels, and will remain this way unless very drastic measures are taken. These are two of the most important pollutants with respect to negative physiological response. By using OzCalc, it was found that concentrations will only approach the WHO standards if a $40 \%$ reduction of $\mathrm{NO}_{2}$ occurs. This would require a dramatic decrease in the number of vehicles on the roads. It was found that this reduction would result in ozone

Table 3: Summary of results of three scenarios, where Scenario 1 is no change, Scenario 2 is $19 \% \mathbf{N O}_{x}$ reduction and Scenario 3 is $\mathbf{4 0 \%} \mathrm{NO}_{2}$ reduction.

\begin{tabular}{|c|c|c|c|c|c|}
\hline Scenario & $\begin{array}{c}\text { Peak }\left[\mathrm{O}_{3}\right] \\
(\mathrm{ppb})\end{array}$ & $\begin{array}{c}\text { Time of } \\
\text { peak }\left[\mathrm{O}_{3}\right]\end{array}$ & $\begin{array}{c}8 \mathrm{~h}\left[\mathrm{O}_{3}\right] \\
\text { Ave (ppb) }\end{array}$ & $\begin{array}{c}{\left[\mathrm{O}_{3}\right] 6: 00 \mathrm{pm}} \\
(\mathrm{ppb})\end{array}$ & {$[\mathrm{NO}] /\left[\mathrm{NO}_{2}\right]$} \\
\hline 1 & 350 & 1:00 PM & 255 & 196 & 0.098 \\
\hline $1 \mathrm{~b}$ & 47.0 & 12:50 PM & 34.5 & 25.7 & 0.200 \\
\hline 2 & 349 & $1: 15 \mathrm{PM}$ & 257 & 202 & 0.096 \\
\hline 3 & 206 & 1:00 PM & 153 & 115 & 0.160 \\
\hline
\end{tabular}


concentrations of $153 \mathrm{ppb}$ at 1:00 pm and $115 \mathrm{ppb}$ at 6:00 $\mathrm{pm}$. According to results found in $\mathrm{OzCalc}$, reducing isoprene within Beijing would make little to no difference in oxidant pollution, therefore a reduction of vegetation would be futile. The NO-to- $\mathrm{NO}_{2}$ concentration ratio must increase in order to create more sinks and less sources of $\mathrm{O}_{3}$ within the city.

Due to Beijing's unique pollution and geography, reduction in sources of $\mathrm{NO}_{2}$ within the city as well as in surrounding municipalities is warranted. This reduction, which can be achieved through Scenario 3, generates considerably lower $\mathrm{O}_{3}$ formation., thus athletes would not have to deal with the associated physiological effects of ozone and PM. In studies of elevated ozone completed by Adams, ${ }^{2}$ Brook et al., ${ }^{9}$ Folinsbee et al., ${ }^{16}$ and others, large decreases in forced expiratory volumes were noted, as well as a large range of inter-individual variability. All concentrations tested in these studies show inhibitory lung responses.

Although this study mainly focused on a few air pollutants, they are not isolated in the atmosphere. There are many synergistic effects between numerous ambient pollutants, as well as the meteorology and environmental factors which effect physiological outcomes. Despite what is known about the air pollution in Beijing, concentrations that will be experienced by athletes are dependent on many variables, ranging from meteorology to governmental initiatives. The gap in our knowledge lies in how the air pollution will affect athletes during high-end competition. Studies have shown inhibitory breathing effects, yet observations of elite athletes during such high profile events are very uncommon. Although measures can be taken to reduce the negative impacts, these can only help to a certain extent. Overall, the boundary layer in Beijing will need to undergo a dramatic loss of air pollution in order for most athletes competing outdoors at the Olympics to achieve world records or even personal bests in their given events.

\section{REFERENCES}

1. Adams, W. C., Savin, W. M., \& Christo, A. E. (1981). Detection of ozone toxicity during continuous exercise via the effective dose concept. Journal of Applied Physiology, 51(3), 415-422.

2. Adams, W. C. (2002). Comparison of chamber and face mask 6.6-hour exposures to ozone on pulmonary function and symptoms responses. Inhalation Toxicology, 14(745), 764.

3. Ando, M., Katagiri, K., Tamura, S., Yamamoto, S., Matsumoto, M., Li, Y. F., et al. (1996). Indoor and outdoor air pollution in Tokyo and Beijing. Atmospheric Environment, 30(5), 695-702.

4. Barrett, L.A., Bunce, N.J., Gillespie, T.J. 1993. Estimation of tropospheric ozone production using concentrations of hydrocarbons and $\mathrm{NO}_{\mathrm{x}}$, and a comprehensive hydrocarbon reactivity parameter.
Journal of Photochemistry and Photobiology. A: Chemistry. 113. 1-8.

5. Beijing 2008: The Official Website of the Beijing 2008 Olympic Games (2007). Retrieved 11/4, from http://en.beijing2008.cn/

6. Beijing International. (2007). Retrieved 11/4, 2007, from http://www.ebeijing.gov.cn/About\%20Beijing/GeIntrod uction/t20041119_184929.htm

7. Bergin, M.H., Cass, G.R., Xu, J., Fang, C., Zeng, L.M., $\mathrm{Yu}, \mathrm{T}$., et al. (2001). Aerosol radiative, physical, and chemical properties in Beijing during June 1999. Journal of Geophysical Research, 106, 17969-17980.

8. Brajer, V., \& Mead, R. W. (2003). Blue skies in Beijing? Looking at the Olympic effect. Journal of Environment and Development, 12(2), 239-263.

9. Brook, R. D., Brook, J. R., Urch, B., Vincent, R., Rajagopalan, S., \& Silverman, F. (2002). Inhalation of fine particulate air pollution and ozone causes acute arterial vasoconstriction in healthy adults. Circulation, 105, 1534-1536.

10. Bunce, N.J. (2007). Personal Communication, Nov. 23, 2007.

11. Bunce, N.J. \& Gillespie, T. J. (2006). MET 4300 Atmospheric Chemistry course notes.

12. Chan, C. T., Xu, X. D., Li, Y. S., Wong, K. H., Ding, G. A., Chan, L. Y., et al. (2005). Characteristics of vertical profiles and sources of $\mathrm{PM}_{2.5}, \mathrm{PM}_{10}$ and carbonaceous aerosols in Beijing. Atmospheric Environment, 39, 5113-5124.

13. Finlayson-Pitts, B. J., \& Pitts, J. N. J. (1986). Atmospheric chemistry: Fundamentals and experimental techniques. New York: Wiley.

14. Florida-James, G., Donaldson, K., \& Stone, V. (2004). Athens 2004: The pollution climate and athletic performance. Journal of Sports Sciences, 22, 967-980.

15. Flouris, A. D. (2006). Modeling atmospheric pollution during the games of the XXVIII Olympiad: Effects on elite competitors. International Journal of Sports Medicine, 27, 137-142.

16. Folinsbee, L. J., Horstman, D. H., Kehrl, H. R., Harder, S., Abdul-Salaam, S., \& Ives, P. J. (1994). Respiratory responses to repeated prolonged exposure to $0.12 \mathrm{ppm}$ ozone. American Journal of Respiratory and Critical Care Medicine, 149(1), 98-105.

17. Foxcroft, W., \& Adams, W. (1986). Effects of ozone exposure on four consecutive days on work performance and $\mathrm{VO}_{2 \max }$. Journal of Applied Physiology, 61, 960966. In Folinsbee et al. (1994). Respiratory responses to repeated prolonged exposure to $0.12 \mathrm{ppm}$ ozone. American Journal of Respiratory and Critical Care Medicine, 149(1), 98-105.

18. Gillespie, T.J. (2008). Personal Communication, Jan. 16, 2008. 
19. Hattis, D., Banati, P., Goble, R., \& Burmaster, D. E. (1999). Human interindividual variability in parameters related to health risks. Risk Analysis, 19(4), 711-726.

20. Huang, X. F., He, L. Y., Hu, M., \& Zhang, Y. H. (2006). Annual variation of particulate organic compounds in $\mathrm{PM}_{2.5}$ in the urban atmosphere of Beijing. Atmospheric Environment, 40, 2449-2458.

21. McCafferty, W. B. (1981). Air pollution and athletic performance. Springfield, Illinois: Thomas Books.

22. Ministry of the Environment. (2007). Air quality Ontario historical weather data. Retrieved 11/25, 2007, from http://www.airqualityontario.ca/

23. Nasa Earth Observatory. (2006). Driving ban lowers Beijing pollution. Retrieved 12/06, 2007, from http://earthobservatory.nasa.gov/Newsroom/NewImages /images.php3?img_id=17649

24. National Research Council. (1991). In Kelly K. (Ed.), Rethinking the ozone problem in urban and regional air pollution. Washington, D.C.: National Academy Press.

25. Schonfeld, B. R., Adams, W. C., \& Schelegle, E. S. (1989). Duration of enhanced responsiveness upon re- exposure to ozone. Archives of Environmental Health, 44(4), 229-337.

26. Streets, G. D., Fu, J. S., Jang, C. J., Hao, J., He, K., Tang, X., et al. (2007). Air quality during the 2008 Beijing Olympic Games. Atmospheric Environment, 41, 480-492.

27. Xiao, H. \& Zhu, B. (2003). Modeling study of photochemical ozone creation potential of non-methane hydrocarbon. Water, Air and Soil Pollution. 145, 3-16.

28. Xu, J., Zhang, Y., \& Wang, W. (2006). Numerical study on the impacts of heterogeneous reactions on ozone formation in the Beijing urban area. Advances in Atmospheric Sciences, 23(4), 605-614.

29. Zhang, Y., Shao, K., Tang, X., \& Li, J. (1998). The study of urban photochemical smog in china. Acta Scientarium Naturalium Universilatis Pekinesis, 34(2-1), 392-400.

30. Zhihui, W., Yuhua, B., \& Shuyu, Z. (2003). A biogenic volatile organics compounds inventory for Beijing. Atmospheric Environment, 37, 3771-3782. 